Acta vet. scand. $1977,18,494-500$.

From the National Veterinary Institute, Oslo, Norway.

\title{
THE RELATIONSHIP OF \\ ERYTHROCYTE GLUTATHIONE PEROXIDASE TO BLOOD SELENIUM IN SWINE*
}

By

Tore Sivertsen, Jan T. Karlsen and Arne Frфslie

SIVERTSEN, TORE, JAN T. KARLSEN and ARNE FRØSLIE: The relationship of erythrocyte glutathione peroxidase to blood selenium in swine. Acta vet. scand. 1977, 18,494-500. - The erythrocyte glutathione peroxidase activity and blood selenium have been investigated in swine fed a Se deficient diet with, and without, selenium supplementation. A highly significant correlation $(r=0.90)$ between erythrocyte glutathione peroxidase and blood selenium was found.

glutathione peroxidase; selenium; swine blood.

Since the discovery that glutathione peroxidase (Glutathione $\mathrm{H}_{2} \mathrm{O}_{2}$ oxido-reductase EC 1.11.1.9 - GSH-Px) is a seleno-enzyme (Rotruck et al. 1973, Flohe et al. 1973), much literature has been published on the GSH-Px-selenium relationship in organs of various species. Thus, a linear correlation between erythrocyte or whole blood GSH-Px activity and blood selenium has been demonstrated in the blood of sheep and cattle (Allen et al. 1975, Oh et al. 1976b, Thompson et al. 1976, Wilson \& Judson 1976). In swine blood, however, Thompson et al. found no such correlation.

The aim of the present investigation was to study the GSH-Px - selenium relationship in the blood of swine fed a Se deficient diet with, and without, selenium supplementation.

* This study was carried out with financial support from the Agricultural Research Council of Norway. 


\section{MATERIALS AND METHODS}

\section{Experimental animals}

The data are derived from 3 experiments on vit. E-selenium deficiency in pigs. All pigs were fed at vit. E-selenium deficient diet from the age of 6 weeks. This diet, based mainly on Se poor barley and Toprina ${ }^{\circledR}{ }^{*}$ single-cell protein, is described in detail by Teige jr. et al. (1977).

Expt. 1 included 24 animals, in 4 groups. Groups 2 and 4 were given a supplement of $200 \mathrm{mg} \alpha$-tocopherol and $0.2 \mathrm{mg}$ selenium ${ }^{\star \star}$ per pig daily, while Groups 1 and 3 were unsupplemented. In addition, the diets of Groups 1 and 2 included $3 \%$ tocopherolstripped $^{\star \star \star}$ cod liver oil. The pigs were bled after 10 weeks of feeding.

Expt. 2 included 6 animals, fed the basic diet with an addition of $5 \%$ tocopherol-stripped cod liver oil. Two of the animals received weekly injections of vit. $E$ and selenium ${ }^{\star \star \star \star}$ equivalent to approx. $0.15 \mathrm{mg}$ Se and $50 \mathrm{mg} \alpha$-tocopherol per $\mathrm{kg}$ feed, while the rest were not treated. The pigs were bled every 2 weeks for a period of 2 months.

Expt. 3 included 24 animals, arranged in 4 groups. They were fed the basic diet with no cod liver oil, and given the following supplements: Group 1: None. Group 2: $200 \mathrm{mg} \alpha$-tocopherol per pig per day. Group 3: $0.2 \mathrm{mg}$ selenium per pig per day. Group 4: $200 \mathrm{mg} \alpha$-tocopherol and $0.2 \mathrm{mg}$ selenium per pig per day. The animals were bled 3 times, at 2 -weekly intervals.

\section{Analytical procedures}

Erythrocyte glutathione peroxidase was determined according to Beutler (1975). A Beckman DB-G spectrophotometer with a temperature controlled sample compartment set at $37^{\circ} \mathrm{C}$ was used. The activity was calculated from the slope of the reaction curve during the first 30 sec. of the reaction, and expressed in i.u. per $\mathrm{g} \mathrm{Hb}$ according to Beutler.

Blood selenium was determined by a fluorometric method

* Produced by British Petroleum.

** As sodium hydroselenite.

* * Subjected to a silica earth absorption treatment, which reduces the tocopherol content (Teige jr. et al. 1977).

$\star \star \star \star$ E-vimin $®$ (Ferrosan) and Tokosel $@$ (Agrivet). 
(Ihnat 1974). The samples $(1-2 \mathrm{ml})$ were digested by a wetdigestion procedure described by Beal (1975).

Serum $\alpha$-tocopherol was determined by a spectrophotometric method (Hashim \& Schuttringer 1966) *.

\section{RESULTS AND DISCUSSION}

A highly significant correlation between erythrocyte glutathione peroxidase and blood selenium in swine blood was found (Fig 1). As seen in Fig. 2, the 2 variables almost parallel each other from week to week in the individual animals.

Separate vit. E supplementation had no effect on erythrocyte GSH-Px activity. On the other hand, the results indicate an elevating effect of selenium/GSH-Px on vit. $\mathrm{E}$ in plasma in the groups not supplemented with vit. E (Table 1).

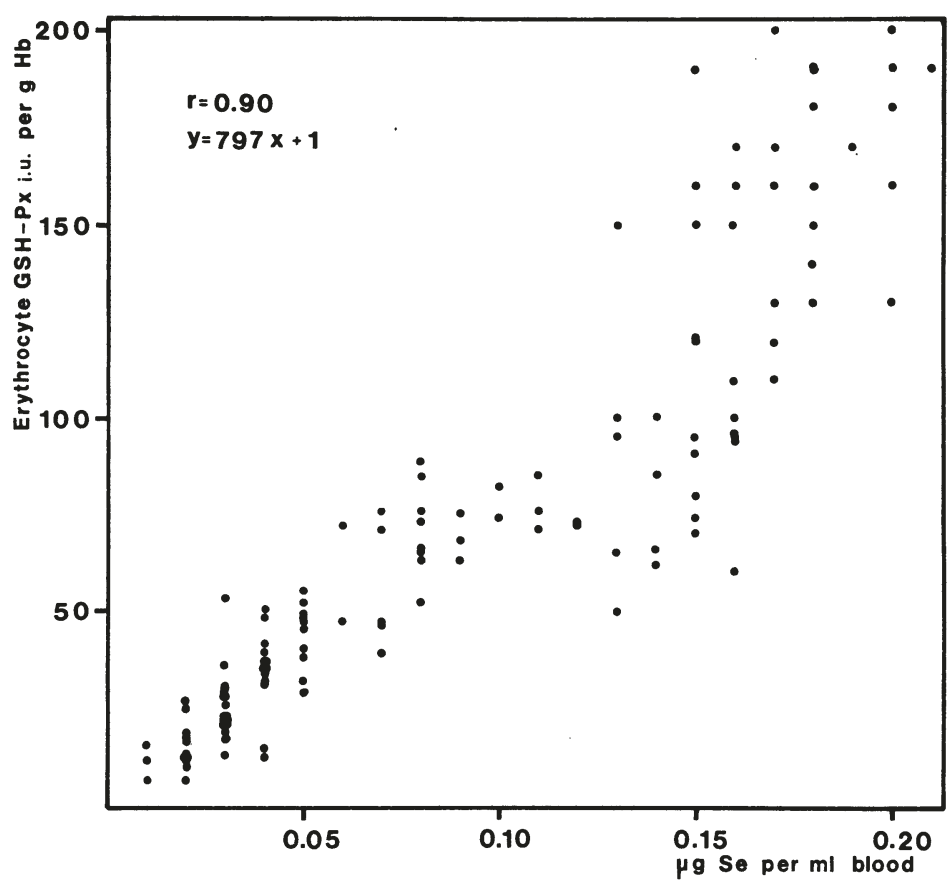

Figure 1. Relationship of erythrocyte GSH-Px activity to blood selenium in swine. The figure shows results of 127 blood samples from

3 experiments on Se-vit. E deficiency, comprising 54 animals. way, Oslo. 


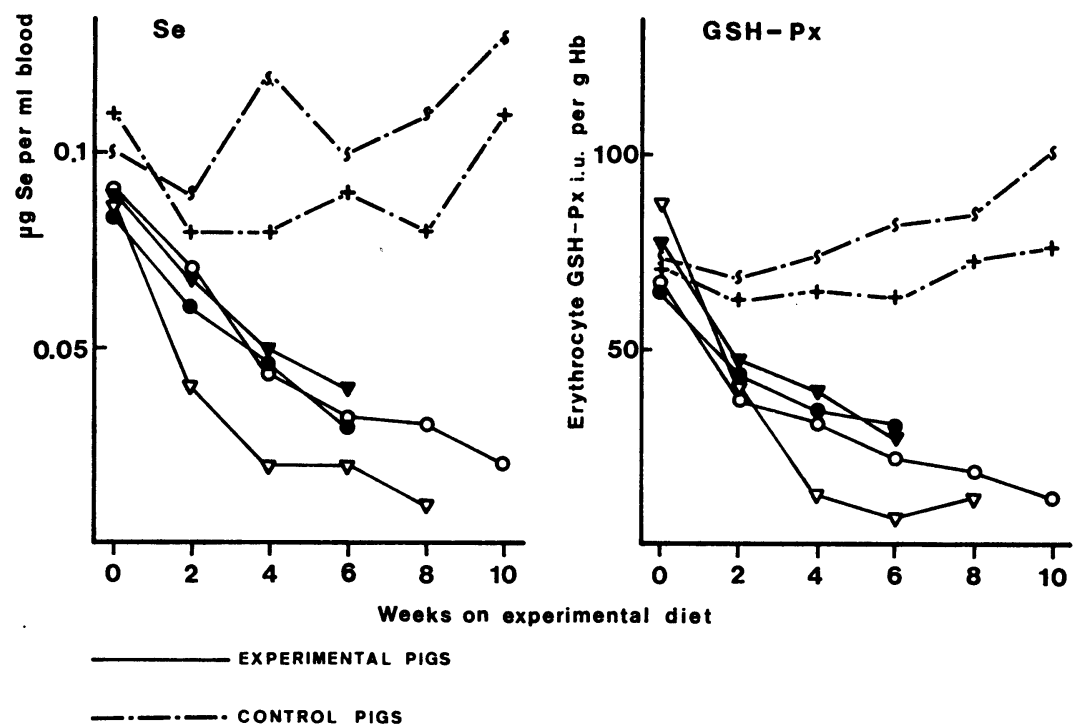

F i g u r e 2. Levels of blood selenium (left) and erythrocyte GSH-Px activity (right) in 4 pigs fed a Se-vit. $\mathrm{E}$ deficient diet with $5 \%$ tocopherol-stripped cod liver oil (Expt. 2). The 2 control pigs were given weekly injections of vit. $E$ and selenium. Three of the experimental pigs died during the experiment, after 7,8 and 9 weeks. The postmortem findings were typical of Se-vit. E deficiency.

T a b le 1. Erythrocyte GSH-Px, blood selenium and plasma $\alpha$-tocopherol in growing swine after 6 weeks on a Se-vit. E. deficient diet with, and without, Se/vit. E supplementation (Expt. 3). Group mean $\pm s$.

\begin{tabular}{lcccc}
\hline & $\begin{array}{c}\text { Group 1 } \\
\text { No supple- } \\
\text { ments }\end{array}$ & $\begin{array}{c}\text { Group 2 } \\
\text { 200 mg } \\
\alpha \text {-tocopherol } \\
\text { per pig daily }\end{array}$ & $\begin{array}{c}\text { Group 3 } \\
\text { 0.2 mg Se } \\
\text { per pig daily }\end{array}$ & $\begin{array}{c}\text { Group 4 } \\
\text { 200 mg } \alpha \text {-toco- } \\
\text { pherol + 0.2 mg } \\
\text { Se per pig daily }\end{array}$ \\
\hline $\begin{array}{l}\text { Erythrocyte } \\
\text { GSH-Px, } \\
\text { i.u. per g Hb }\end{array}$ & $28 \pm 7$ & $29 \pm 8$ & $150 \pm 40$ & $120 \pm 40$ \\
$\begin{array}{l}\text { Blood Se, } \\
\mu \text { g per ml }\end{array}$ & $0.04 \pm 0.01$ & $0.03 \pm 0.01$ & $0.19 \pm 0.02$ & $0.16 \pm 0.02$ \\
$\begin{array}{l}\text { Plasma } \\
\alpha \text {-tocopherol }\end{array}$ & & & & \\
$\mu$ M per ml & $0.7 \pm 0.4$ & $2.8 \pm 0.3$ & $1.2 \pm 0.2$ & $3.1 \pm 1.0$ \\
\hline
\end{tabular}

* These values will also be published elsewere (Teige jr. et al. in press). 
The inclusion of $3 \%$ cod liver oil in the diet (Expt. 1) did not influence GSH-Px activity.

The erythrocyte GSH-Px activity has previously been shown to be a useful indicator of the Se balance in rats (Hafeman et al. 1974, Reddy \& Tappel 1974, Smith et al. 1974), chickens (Omaye \& Tappel 1974) and sheep (Oh et al. 1976 a, b). As mentioned, several authors have reported a linear correlation between erythrocyte or whole blood GSH-Px and blood Se in sheep and cattle (Allen et al. 1975, Oh et al. $1976 \mathrm{~b}$, Thompson et al. 1976, Wilson \& Judson 1976). This indicates that GSH-Px activity can be used as a direct parameter for blood Se status. Based on these results, a simplified GSH-Px method has been developed for field tests for selenium deficiency in sheep (Board \& Peter 1976).

Our results indicate that erythrocyte GSH-Px activity may be used as a direct parameter of blood Se status also in swine. This is in contrast to the findings of Thompson et al.

Recently, Bengtsson et al. (1976) reported a close correlation between serum GSH-Px activity and blood selenium in swine.

Selenium levels in the present material range from normal to extreme deficiency. This also applies to the other reports mentioned.

In a study in man, no correlation was found between GSH$P x$ and total Se in erythrocytes (Schmidt \& Heller 1976).

The finding that dietary vit. $E$ has no influence on pig erythrocyte GSH-Px activity corresponds with the results of Fukuzawa \& Tokumura (1976) in the mouse, but not with those of Scott et al. (1976) in the rat.

The lack of influence of unsaturated lipids in the diet on erythrocyte GSH-Px activity does not correspond with the results of Reddy \& Tappel in the rat. However, their experimental diet included as much as $15 \%$ tocopherol-stripped corn oil.

\section{REFERENCES}

Allen, W. M., W. H. Parr, P. H. Anderson, S. Berrett, R. Bradley \& D. S. P. Patterson: Selenium and the activity of glutathione peroxidase in bovine erythrocytes. Vet. Rec. 1975, 96, 360—361.

Beal, A. R.: Selenium determination on fish tissue. J. Fish. Res. Board Can. 1975, 32, 249-252. 
Bengtsson, G., J. Hakkarainen, L. Jönsson, P. Lindberg \& N. Lannek: The requirement for selenium and vitamin $E$ in weaned pigs. Int. Pig Vet. Soc., 4th Int. Congr., Ames 1976.

Beutler, E.: Red Cell Metabolism. A Manual of Biochemical Methods. 2nd Ed. Grune \& Stratton, New York 1975, 160 pp.

Board, P. G. \& D. W. Peter: A simple test for glutathione peroxidase and selenium deficiency. Vet. Rec. 1976, 99, 144-145.

Flohe, L., W. A. Günzler \& H. H. Schock: Glutathione peroxidase: A selenoenzyme. FEBS Lett. 1973, 32, 132-134.

Fukuzawa, K. \& A. Tokumura: Glutathione peroxidase activity in tissues of vit. E-deficient mice. J. Nutr. Sci. Vitaminol. 1976, $22,405-407$.

Hafeman, D. G., R. A. Sunde \& W. G. Hoekstra: Effect of dietary selenium on erythrocyte and liver glutathione peroxidase in the rat. J. Nutr. 1974, 104, 580-587.

Hashim, S. A. \& G. R. Schuttringer: Rapid determination of tocopherol in macro- and microquantities of plasma. Amer. J. clin. Nutr. 1966, 19, 137-145.

Ihnat, M.: Fluorometric determination of selenium in foods. J. Ass. Off. Anal. Chem. 1974, 57, 368-372.

Oh, S-H., R. A. Sunde, A. L. Pope \& W. G. Hoekstra: Glutathione peroxidase response to selenium intake in lambs fed a torula yeast based, artificial milk. J. Anim. Sci. 1976a, 42, 977-983.

Oh, S-H., A. L. Pope \& W. G. Hoekstra: Dietary selenium requirement of sheep fed a practical-type diet as assessed by tissue glutathione peroxidase and other criteria. J. Anim. Sci. 1976b, 42, 984-992.

Omaye, S. T.\& A. L. Tappel: Effect of dietary selenium on glutathione peroxidase in the chick. J. Nutr. 1974, 104, 747-753.

Reddy, K. \& A. L. Tappel: Effect of dietary selenium and autoxidized lipids on the glutathione peroxidase system of gastrointestinal tract and other tissues in the rat. J. Nutr. 1974, 104, 1069-1078.

Rotruck, J. T., A. L. Pope, H. E. Ganther, A. B. Swanson, D. G. Hafeman \& W. G. Hoekstra: Selenium: Biochemical role as a component of glutathione peroxidase. Science 1973, 179, 588-590.

Schmidt, K. \& W. Heller: Selenkonzentration und Aktivität der Glutathion-peroxydase im Lysat menschlicher Erythrozyten. (Selenium concentration and activity of glutathione peroxidase in lysate of human erythrocytes). Blut 1976, 33, 247-251.

Scott, D. L., J. Kelleher \& M. S. Losowsky: The effect of dietary selenium and vitamin $\mathrm{E}$ on glutathione peroxidase and glutathione in the rat. Biochem. Soc. Trans. 1976, 4, 295-296.

Smith, P. J., A. L. Tappel \& C. K. Chow: Glutathione peroxidase activity as a function of dietary selenomethionine. Nature (Lond.) 1974, 247, 392-393. 
Teige jr., J., K. Nordstoga \& J. Aursjø: Influence of diet on experimental swine dysentery. 1. Effects of a vitamin $E$ and selenium deficient diet supplemented with 6.8\% cod liver oil. Acta vet. scand. 1977, 18, 384-396.

Teige jr., J., F. Saxegaard \& A. Frøslie: Influence of diet on experimental swine dysentery. 2. Effects of a vitamin $\mathrm{E}$ and selenium deficient diet supplemented with $3 \%$ cod liver oil, vitamin $\mathrm{E}$ or selenium. In press.

Thompson, R. H., C. H. McMurray \& W. J. Blanchflower: The levels of selenium and glutathione peroxidase activity in blood of sheep, cows and pigs. Res. vet. Sci. 1976, 20, 229-231.

Wilson, P. S. \& G. J. Judson: Glutathione peroxidase activity in bovine and ovine erythrocytes in relation to blood selenium concentration. Brit. vet. J. 1976, 132, 428-434.

\section{SAMMENDRAG}

Forholdet mellom glutathion peroksydaseaktivitet $i$ r $\phi$ de blodlegemer og selenkonsentrasjon $i$ blod hos svin.

Aktiviteten av glutathion peroksydase (GSH-Px) i røde blodlegemer og konsentrasjonen av selen i blod er målt hos griser som ble satt på selen/E-vitaminfattig fór fra 6-ukers alder. Grisene fikk dels tilskudd av selen, dels av E-vitamin, dels både selen og E-vitamin, i tillegg til at noen griser fikk tilskudd av E-vitaminfattig tran.

Det ble funnet en positiv, lineær korrelasjon mellom blodkonsentrasjonen av selen og GSH-Px aktiviteten i blodlegemene $(r=0,90$; $\mathrm{y}=797 \mathrm{x}+1 ; \mathrm{n}=127)$. Hverken trantilskudd eller E-vitamintilskudd alene hadde noen effekt på aktiviteten av GSH-Px i blodlegemene.

(Received June 13, 1977).

Reprints may be requested from: The National Veterinary Institute, P. O. Box 8156, Oslo Dep., Oslo 1, Norway. 